Liljana Kola * ${ }^{*}$ Pranvera Lazo ${ }^{2}$

${ }^{1}$ University of Tirana, Institute of Applied Nuclear Physics, Albania, Rr. 'Thoma Filipeu', Qesarakë, Tirana, Albania

${ }^{2}$ University of Tirana, Albania, Department of Chemistry, Faculty of Natural Sciences, Blv 'Zogu I parë', Tirana, Albania
Scientific paper

ISSN 0351-9465, E-ISSN 2466-2585

UDC:628.161.2:661.183.2

doi:10.5937/zasmat1804501K

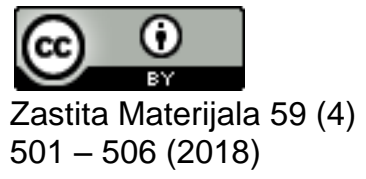

\title{
Determination of SRG extra recovery degree from activated carbon used in water environment studies
}

\begin{abstract}
The purpose of this paper relates to determining the adsorption and recovery degree from activated carbon bags of Sulphorhodamine G Extra (SRG Extra) which can be used as fluorescent tracer in studies of aquatic environments. The effect of the activated carbon is that traces of the used dye are strongly fixed at the surface of the carbon grains. This attribute is used in different water systems studies with fluorescent tracer experiments. Carbon bags are used for the first time in our country in karst system study of Mali me Gropa (2002). Adsorbed tracer can be extracted from carbon bags under the analytical procedures. Based on measurements of SRG Extra fluorescence intensity in standard solutions and extracts we can calculate its adsorption and recovery degree from activated carbon bags. The obtained results prove that extreme low traces of SRG Extra, which cannot be detected directly in the water sample, can be determined in carbon extracts.
\end{abstract}

Keywords: Synchronous scan, Fluorescence Intensity $\left(I_{F}\right)$, Activated carbon, Artificial tracer, SRG Extra.

\section{INTRODUCTION}

The introduction of fluorescent tracers in hydrology has led to enormous methodological and instrumental developments. System's water is labelled through fluorescent dyes as artificial tracers and then their presence is monitored from time to time in various parts of the system under the study. We can take this information measuring the dyes fluorescence intensity directly in water samples or in activated carbon bags extracts.

Granular activated carbon is a particularly good adsorbent medium due to its high surface area to volume ratio. One gram of a typical commercial activated carbon will have a surface area equivalent to 1,000 square meters. This high surface area permits the accumulation of a large number of contaminant molecules. The specific capacity of a granular activated carbon to adsorb organic compounds is related to: molecular surface attraction, the total surface area available per unit weight of carbon, and the concentration of contaminants in the wastewater stream [1].

\footnotetext{
${ }^{*}$ Corresponding author: Liljana Kola

E-mail: kolaliljana@yahoo.it

Paper received: 20. 09. 2018.

Paper accepted: 01. 11. 2018.

Paper is available on the website: www.idk.org.rs/journal
}

Activated carbon is widely used for different purposes as good adsorbent in the removal of herbicide from water and other purposes $[2,3]$.

Synthetic organic compounds in water which include most of the herbicides are a major concern and cause of health risks in water supply systems. Advanced treatment processes such as powder activated carbon adsorption and granular activated carbon adsorption are effective in removing the herbicides [4]. Some other results illustrate that granular activated carbon is an effective adsorbent for methyl tert-butyl ether and also provide specific guidance into adsorption of methyl tert-butyl ether on granular activated carbon in contaminated groundwater [5].

We will present in this paper some experiments about the ability of activated carbon to fix strongly SRG Extra at its grains surface. We have calculated the adsorption and recovery degree of SRG Extra from activated carbon bags used in water system studies.

\section{EXPERIMENTAL}

A container with grains of activated carbon is put into the water for one day or up to several weeks. The great advantage of this method is that springs or wells need not to be sampled continuously. Extreme low traces of dyes, which cannot be detected by spectrofluorometer directly 
from the water sample, can be determined in carbon extracts. The effect of the activated carbon is that traces of the used dye are strongly fixed at the surface of the carbon grains. They will not be washed out during a longer period of exposition. The dye will be enriched in the carbon and the measured concentrations of the dye in the extracts are 10 to 1000 times higher than average concentrations measured in the water samples of the same period. A disadvantage is that only qualitative results are available, because the exact concentration related to a certain volume of water and the time when the dye has been adsorbed is unknown. Furthermore the upper limit of the adsorption capacity with regard to the natural background quality of the water is unknown too. So the results are normally given in scale units or relative intensity $[6,7]$.
We have used SRG Extra standard solution and active carbon bags (MERCK 2514) to determine the absorption and recovery of SRG Extra from carbon bags. The recovery of carbon active needs some special conditions.

Carbon bags recommended by Bauer (Fig. 1) contain an activated carbon with a grain size 1.5 $\mathrm{mm}$ (MERK, FRG No 2515). The material of the bag is nylon with a mesh width of $0.5-0.7 \mathrm{~mm}$.

The exposition to the water should be such that the bag is fully immersed. One has to be sure that the water can flow through very well. After collecting them from the sampling points, we hang the bags on a cord for drying in the air for 1 or 2 days, in the laboratory.

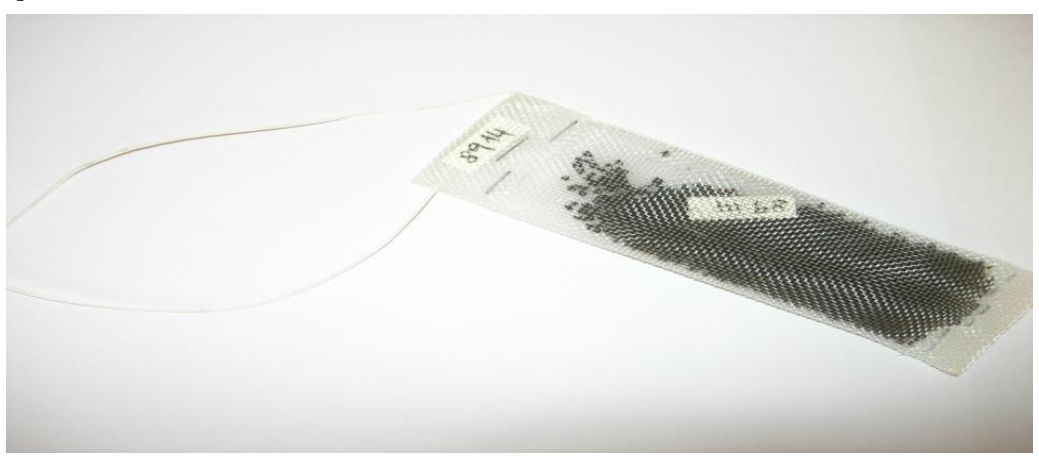

Figure 1: Carbon bag ( Bauer)

Slika 1. Vreća aktivnog uglja (Bauer)

Weighing of a quantity dried activated carbon was carried out by the means of an analytic balance (OHAUS Model GJ 610-2M) with $0.005 \mathrm{~g}$ reproducibility and $\pm 0.01 \mathrm{~g}$ linearity. The extraction of SRG Extra from the dried activated carbon is carried out with a mixture that contains $\mathrm{N}, \mathrm{N}$ Dimethylformamide (DMF) : distilled water $\mathrm{H}_{2} \mathrm{O}$ in 80:20 ratio in a glass test tube with a flat bottom and afterwards shaked in darkness for 1 to 2 hours in the shaker KIKA HS 501 digital. Finally the testtubes are let in a dark compartment for another hour to allow all suspended material to fall down [79].

The concentration and synchronous scan methods were used for the measurement of SRG Extra fluorescence in standard samples and carbon bags extracts by the means of a Perkin Elmer Luminescence Spectrometer LS 55.

A special software package (FL WinLab) manages different application programs the instrument LS 55 offers. First the instrument stability is checked with regard to fluorescence intensity by the means of a reference material (Anthracene) [10]. The measurements validation with LS 55 instrument should be realized through
Raman spectra (Raman Peak Wavelength, Raman Peak Intensity and Raman S/N ratio) from a sealed water cell [11]. and reference material. The method elaborated to measure SRG Extra fluorescence intensity is made up of the following parameters: Excitation wavelength- $531 \mathrm{~nm}$; Emission wavelength- $552 \mathrm{~nm}$; Ex. slit- $10.0 \mathrm{~nm}$; Em. slit$10.0 \mathrm{~nm} ; \Delta \lambda-25 \mathrm{~nm}$; etc. The instrument was previously calibrated with SRG Extra standard solutions by the means of the calibration application. Chemical treatment procedure has been applied for both samples and standards. We have previously analyzed some "blanks" in order to assess the natural presence of SRG Extra fluorescence, the so called "background".

\section{RESULTS AND DISCUSSION}

\section{a. Determination of SRG Extra adsorption degree from activated carbon bags}

Determination of the degree of adsorption of SRG Extra from activated carbon bags, in our lab conditions, is described below.

It was prepared a SRG Extra standard solution and it was measured its fluorescence concentration $\mathrm{C}_{0 \mathrm{SSt}}=1.883 \mathrm{ppb}$ (by the means of a Perkin Elmer 
Luminescence Spectrometer LS 55). We took six sterile plastic bottles of $250 \mathrm{ml}$ volume and were added in $100 \mathrm{ml}$ standard solution of SRG Extra. In each of this bottle was introduced a carbon bag and the bottles were placed in horizontal position in the shaker. We controlled the carbon bags to be sure that they were completely immersed in the SRG Extra standard solutions. After that we applied different shaking time periods to each of the plastic bottle, namely $1 \mathrm{~min}, 4 \mathrm{~min}, 7 \mathrm{~min}, 10$ min, 30 and 60 min. Carbon bags were removed from bottles and hang them for drying. The respective solutions in six sterile plastic bottles were measured again for remained fluorescence of SRG Extra not adsorbed from active carbon - $\mathrm{C}_{\mathrm{SRG}}$ Sol or $\mathrm{C}_{\mathrm{SS}}$ (ppb) (Fig. 2).

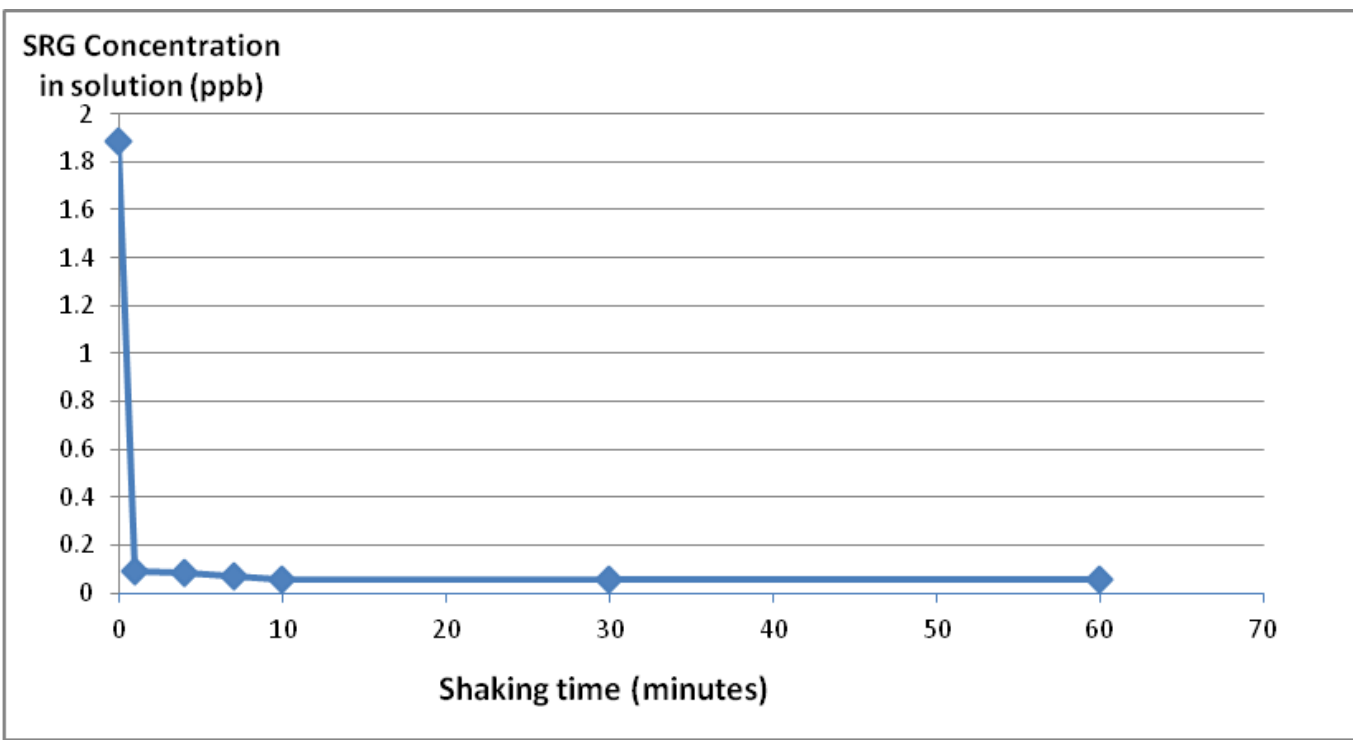

Figure 2. SRG concentrations in solution after being in contact with carbon bags for different shaking time

Slika 2. SRG koncentracije u rastvoru nakon što su bile u kontaktu sa aktivnim ugljem za različita vremena

These values were calculated in percentage, $\mathrm{C}_{\mathrm{SSol}}(\%)$, making reference to the concentration of SRG Extra standard solution $\left(\mathrm{C}_{0 \mathrm{~S}}\right.$ sol st $\left.=1.883 \mathrm{ppb}\right)$.

Adsorption degree of SRG Extra $A_{S}(\%)$ from active carbon in different time is calculated from the formula:

$$
A_{S}(\%)=\frac{C_{0 S S t}-C_{S s o l}}{C_{\text {OSSt }}} 100
$$

Where: $\mathrm{C}_{0 S s t}$ - SRG Extra standard solution $1.883 \mathrm{ppb}$

Table 1. Adsorption degree of SRG Extra (As) from activated carbon $\left(C_{0 S S t}=1.883 p p b\right)$

Tabela 1. Stepen adsorpcije SRG Extra $(A s)$ iz aktivnog uglja $\left(C_{0 S S t}=1.883\right.$ ppb)

\begin{tabular}{|c|c|c|c|c|}
\hline Nr. of carbon bag & $\begin{array}{c}\text { Shaking time } \\
\text { (minutes) }\end{array}$ & $\begin{array}{c}\text { Conc SRG } \\
\text { In solution Cssol (ppb) }\end{array}$ & Cssol (\%) & $\begin{array}{c}\text { Adsorption degrees } \\
A_{S}(\%)\end{array}$ \\
\hline 8680 & 1 & 0.093 & 4.94 & 95.06 \\
\hline 8672 & 4 & 0.084 & 4.46 & 95.54 \\
\hline 8671 & 7 & 0.074 & 3.93 & 96.07 \\
\hline 8679 & 10 & 0.057 & 3.03 & 96.97 \\
\hline 8915 & 30 & 0.055 & 2.92 & 97.08 \\
\hline 8911 & 60 & 0.054 & 2.87 & 97.13 \\
\hline
\end{tabular}

Dependence of SRG Extra adsorption degrees from the different shaking time periods is shown in figure 3 .
$\mathrm{C}_{\mathrm{SSol}}$ - remained fluorescence of SRG Extra in solution, not adsorbed from active carbon (ppb).

Obtained results of SRG concentrations remained in solution $\mathrm{C}_{\mathrm{SSol}}(\mathrm{ppb}$ and \%) after being in contact with carbon bags for different shaking time periods are presented in table 1 and graphically in figure 2 .

SRG Extra adsorption respective degrees $\left(A_{S}\right.$ $\%)$ from activated carbon. are presented in table 1 , too. 


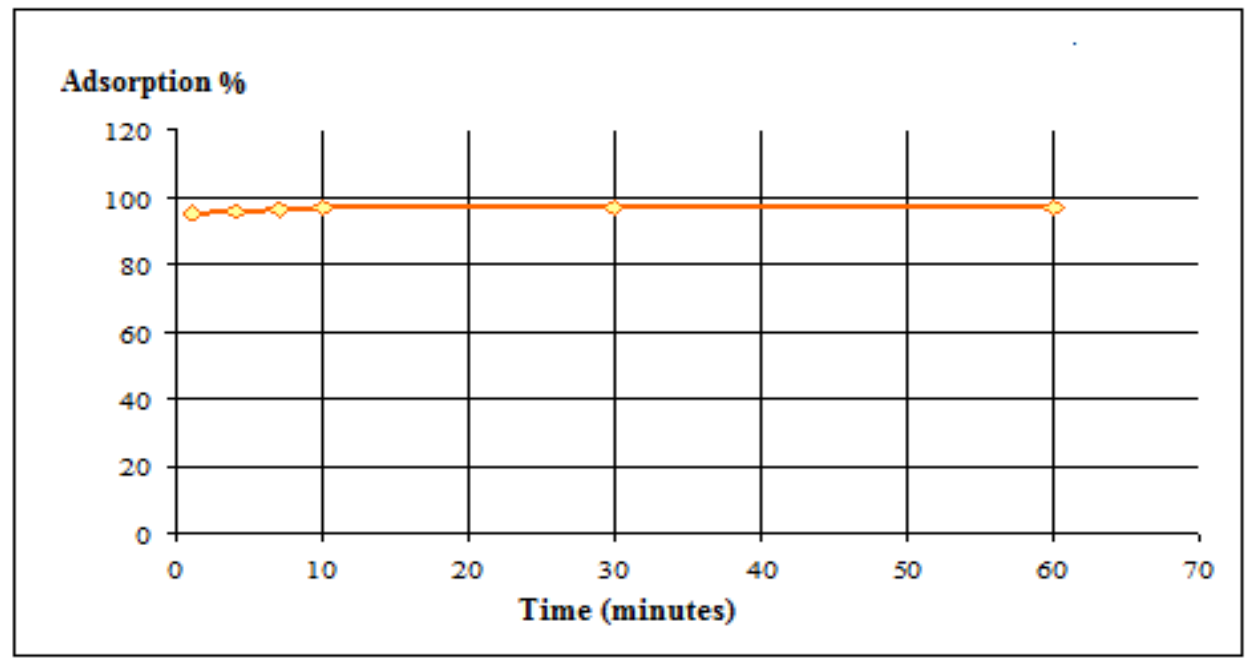

Figure 3. Adsorption degree of SRG Extra $\left(A_{S}\right)$ from activated carbon

Slika 3. Stepen adsorpcije SRG Extra $\left(A_{s}\right)$ iz aktivnog uglja

This experiment showed that activated carbon adsorbed $95.06 \%$ of SRG Extra just for one minute shaking time and $97.13 \%$ after 60 minutes. These results proved that SRG Extra was rapidly and strongly fixed at the surface of the activated carbon grains, so using the carbon bags in water system studies with SRG Extra, as artificial tracer, is helpful and convenient.

\section{b. Determination of SRG Extra recovery degree from activated carbon bags}

According to our results, presented in table 2 and figure 4, the maximum extraction of SRG Extra from the same active carbon bag which contained adsorbed SRG Extra, can be achieved by the mixture $\mathrm{N}, \mathrm{N}$-Dimethylformamide (DMF): distilled water $\mathrm{H}_{2} \mathrm{O}$ in the ratio 80:20.

Table 2. SRG Extra extraction from the same carbon bag with different mixture

Tabela 2. SRG Extra ekstrakcija iz iste ugljene kese sa različitim smešama

\begin{tabular}{|c|c|c|c|}
\hline Nr. of carbon bag & Mixture & Fluorescence Intensity & Concentration CsS extract $_{\text {(ppb) }}$ \\
\hline 8777 NLCSRG, 1 & Distilled water & 2.590 & 0.042 \\
\hline 8777 NLCSRG, 2 & Ethanol : KOH 50:50 & 10.815 & 0.172 \\
\hline 8777 NLCSRG, 3 & DMF: Dist. water 80:20 & 31.841 & 0.506 \\
\hline
\end{tabular}

\section{Fluorescence \\ Intensity}

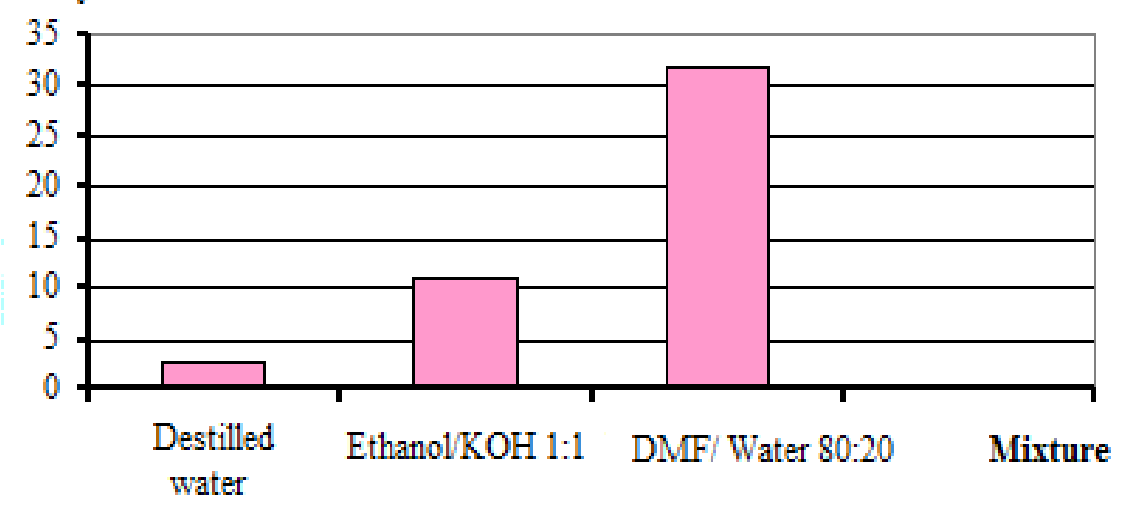

Figure 4. Influence of the mixtures on SRG Extra fluorescence intensity

Slika 4. Uticaj smeša na SRG Extra intenzitet fluorescencije 
Determination of the recovery degree of SRG Extra from activated carbon bags, in our lab conditions, is described shortly below.

We used the same carbon bags used for the determination of SRG Extra adsorption degree (8680, 8672, 8671, 8679, 8915, 8911) (see tab.1) and tried to extract from them the adsorbed SRG Extra.

We weighted $0.5 \mathrm{gr}$ carbon from dried carbon bags and extracted the SRG Extra from them with $7 \mathrm{ml}$ mixture DMF: distilled water in 80:20 ratio. The concentrations of SRG Extra were measured in obtained extracts $\left(\mathrm{C}_{\mathrm{SRG} \text { Ext }}\right)$ for different extraction time from one to 60 minutes.
The degree of recovery of SRG Extra $\left(R_{S}\right)$ for each extraction time was calculated by comparing the amount of SRG Extra in extract $\left(Q_{S \text { Ext }}\right)$ with its adsorbed amount from active carbon $\left(Q_{S}\right.$ Ads $)$, expressed in percentage:

$$
R s(\%)=\frac{Q S E x t}{Q S_{A d S}} 100
$$

After appropriate calculations the obtained values of the recovery degree of SRG Extra $\left(R_{S}\right)$ from activeted carbon for different extraction time are shown in table 3.

Tab. 3: Recovery degree of $S R G$ Extra $\left(R_{S}\right)$ from carbon bags with adsorbed $S R G$ Extra

Tabela 3. Stepen oporavka SRG Extra (RS) iz ugljenih kesa sa adsorbovanim SRG Extra

\begin{tabular}{|c|c|c|c|c|}
\hline $\begin{array}{c}\text { Nr. of carbon } \\
\text { bag }\end{array}$ & $\begin{array}{c}\text { Extraction time } \\
\text { (minutes) }\end{array}$ & $\begin{array}{c}\text { Adsorbed SRG } \\
\text { Qs Ads (ppb) } \\
1.883-\text { CSSol }_{\text {ss }}\end{array}$ & $\begin{array}{c}\text { Extracted SRG } \\
\text { Qs Ext }\end{array}$ & $\begin{array}{c}\text { Recovery degree } \\
\text { Rs }(\%)\end{array}$ \\
\hline 8680 & 1 & 1.790 & 0.210 & 12.32 \\
\hline 8672 & 4 & 1.799 & 0.222 & 12.96 \\
\hline 8671 & 7 & 1.809 & 0.245 & 14.22 \\
\hline 8679 & 10 & 1.826 & 0.263 & 15.12 \\
\hline 8915 & 30 & 1.828 & 0.285 & 16.37 \\
\hline 8911 & 60 & 1.829 & 0.304 & 17.45 \\
\hline
\end{tabular}

Figure 5 shows the dependence of the degree of recovery of SRG Extra from the time of extraction from active carbon.

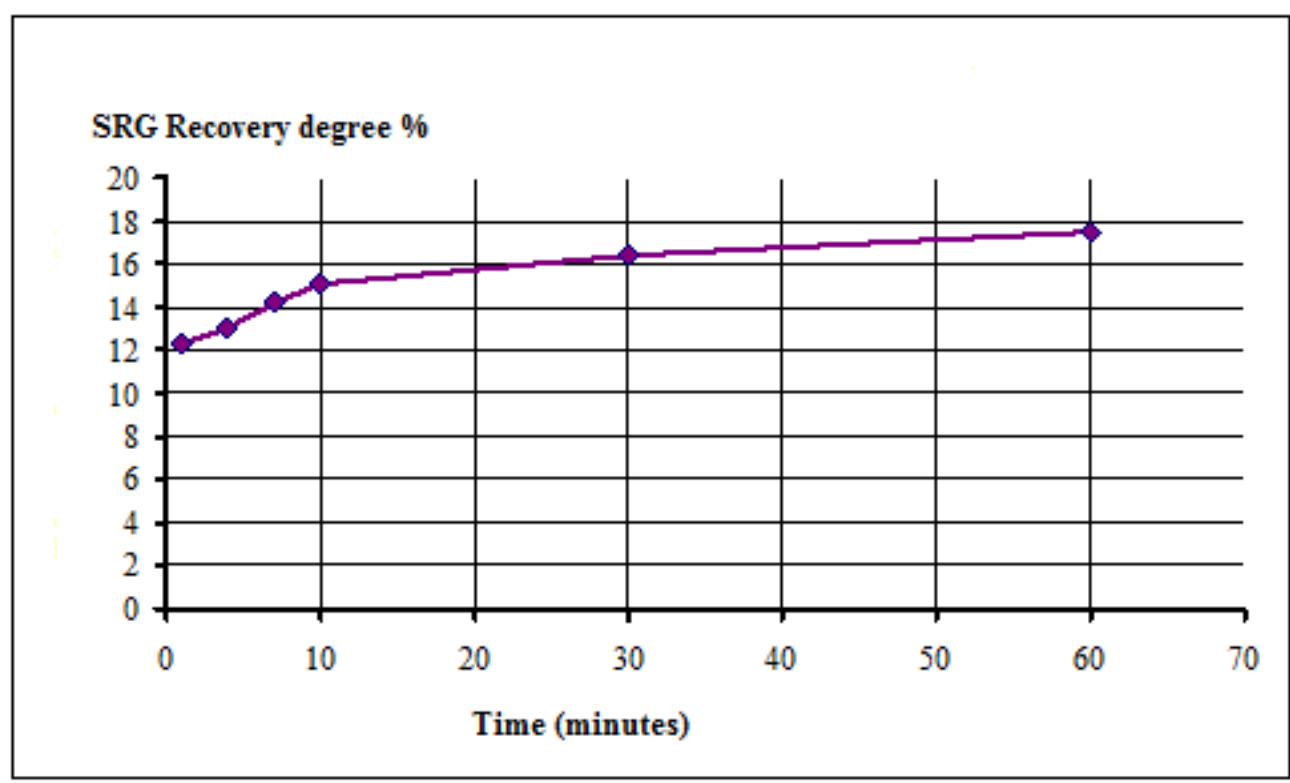

Figure 5. Recovery degree of SRG Extra from activated carbon

\section{Slika 5. Stepen oporavka SRG Extra iz aktivnog uglja}

As seen from the results presented in the table 3 and in the figure 5, the degree of recovery of SRG Extra from active carbon varies from $12.32 \%$ for one minute extraction, until $17.45 \%$ for 60 minutes extraction time period. 


\section{CONCLUSIONS}

According to our results the particles of the activated carbon adsorb $95.06 \%$ of SRG Extra just in one minute after having been in contact with water containing tracer, so it seems clear that the carbon grains fix very rapidly the fluorescent dye.

The degrees of recovery of SRG Extra from active carbon are $12.32 \%$ to $17.45 \%$ for the extraction time period from one to 60 minutes.

The obtained values of the recovery degrees of SRG Extra from active carbon look to be small values but they are very significant if we consider that the measured concentrations of the dye in the extracts are 10 to 1000 times higher than average concentrations measured in the water samples of the same period. The carbon bags can be used only to prove whether the dye has passed or not at sampling points where they are located.

The obtained results prove that the use of the carbon bags in water system studies with fluorescent tracer is very helpful and convenient.

\section{REFERENCES}

[1] P.Shepherd, R.Austin (1992) Granular Activated Carbon For Water \& Wastewater Treatment, Carbtrol $\AA$ Corporation, Rev. 10/92, TP-3, Bridgeport, Connecticut, USA.

[2] A.Bach, R.Zelmanov, G.Semiat (2008) Cold catalytic recovery of loaded activated carbon using iron oxide-based nanoparticles, Elsevier Ltd, IWA Publishing, 42(1-2), 163-168.
[3] Jon D.Snyder, R.Leesch, G.James (2001) Methyl Bromide Recovery on Activated Carbon with Repeated Adsorption and Electrothermal Regeneration, Ind. Eng. Chem. Res., 40, ACS Publications, p. 2925-2933

[4] N.Areerachakul, S.Vigneswaran (2007) Granular activated carbon (GAC) adsorption-photocatalysis hybrid system in the removal of herbicide from water, ScienceDirect, (C) 2007, Elsevier B.V., p. 206211.

[5] D.ZChen, J.X.Zhang, J.M.Chen (2010) Adsorption of methyl tert-butyl ether using granular activated carbon: Equilibrium and kinetic analysis, Int. J. Environ. Sci. Tech., 7(2), 235-242.

[6] R. Benischke (1991) Fluorescent Tracers in Hydrology; book, Graz, p. 32-36.

[7] W. Käss (1994) Tracing Technique in Geohydrology; book, Berlin, p. 19-105.

[8] L.Kola, S.Amataj (2006) The Influence of Some Chemical and Physical Parameter of Water Samples on Spectral Determination, Bulletin of Chemist and Technologists of Macedonia, 25(2), 107-112.

[9] L.Kola (2008) Optimization of Fluorometric Determinations in Water Samples and Active Coal Samples, Ph.D. Thesis, Tirana University, p.46-49, 125-131.

[10] Perkin Elmer Ltd. (2000) Fluorescence Intensity Samples; C520-7440, Booklet, Perkin Elmer inc., p. 3, 10, Buckinghamshire, UK.

[11] Perkin Elmer Ltd.-2 (2000) Molecular Spectroscopy, LS 55 User's Guide, Perkin Elmer inc., p. 191-196, 283-287, Buckinghamshire, UK.

\title{
IZVOD \\ ODREĐIVANJE SRG DODATNOG STEPENA OPORAVKA AKTIVNOG UGLJA KOJI SE KORISTI U ISTRAŽIVANJU VODENE SREDINE
}

Svrha ovog rada se odnosi na određivanje stepena adsorpcije $i$ oporavka vreća sa aktivnim ugljem od Sulphorhodamine G Ekstra (SRG Extra), koji se može koristiti kao fluorescentni tragač u studijama o vodenoj sredini. Efekat aktiviranog uglja je da su tragovi korišćene boje snažno fiksirani na površini ugljeničnih zrna. Ovaj atribut se koristi u različitim studijama vodenih sistema sa fluorescentnim tragačkima u eksperimentima.

Ugljene vrećice se prvi put koriste u našoj zemlji u studiji karst sistema za "Mali me Gropa" (2002). Adsorbovani tragač se može izvući iz ugljenih vreća u analitičkim postupcima. Na osnovu merenja SRG Extra intenziteta fluorescencije u standardnim rastvorima i ekstraktima možemo izračunati njegov stepen adsorpcije i oporavka aktivnog uglja u kesama. Dobijeni rezultati dokazuju da ekstremno niski tragovi SRG Extra, koji se ne mogu direktno detektovati u uzorku vode, mogu biti određeni u ekstraktima ugljenika.

Ključne reči: sinhrono skeniranje, intenzitet fluorescencije (IF), aktivni ugalj, veštački tragač, ekstra SRG.

\author{
Naučni rad \\ Rad primljen: 30. 09. 2018. \\ Rad prihvaćen: 01. 11. 2018. \\ Rad je dostupan na sajtu: www.idk.org.rs/casopis
}

(C) 2018 Authors. Published by Engineering Society for Corrosion. This article is an open access article distributed under the terms and conditions of the Creative Commons Attribution 4.0 International license (https://creativecommons.org/licenses/by/4.0/) 